\title{
Effect of Brainstorming strategy on Senior Secondary School Students' Academic Achievement in Chemistry in Rivers State, Nigeria
}

\author{
Samuel O. Wagbara (Ph.D) ${ }^{\mathbf{1}}$ \\ ${ }^{1}$ Department of Integrated Science \\ Faculty of Natural and Applied Sciences \\ Ignatius Ajuru University of Education \\ Port Harcourt, Nigeria
}

\begin{abstract}
The paradigm shift of modern teaching and learning of Chemistry tilt towards activity oriented strategies that focus on creative thinking and team work to build new ideas. Hence, the main purpose of this study was to determine the effect of brainstorming strategy on senior secondary school student's academic achievement in chemistry. This study adopted quasi experimental research design. A sample of (200) SS2 Chemistry students who were obtained by simple random sampling by balloting participated in the study. The data collected were analyzed by using mean and standard deviation to answer the research questions while Analysis of co-variance (ANCOVA) was used for testing the hypotheses at 05 level of significance. The study found that brainstorming had significant effect $P<.05$ on students mean achievement score in Chemistry. There was significant difference between the mean achievement scores of students exposed to brainstorming strategy in Chemistry $P<.05$ and those of lecture method in favor of brainstorming strategy. Gender does not have significant effect $P>.05$ on students taught Chemistry by use of brainstorming strategy. Hence, it becomes necessary for chemistry teachers to use brainstorming strategy in order to boost the academic achievement of students in chemistry.

Key words: paradigm, experimental research, Chemistry, particular phenomenon, Collaborative learning.
\end{abstract}

\section{Introduction}

In this era of science and technological advancement that is engulfed with positive changes and knowledge explosion. The idea of seeing the teacher as a repository of knowledge or an individual to be endowed with all the required knowledge of a particular phenomenon is now obscure. Hence, the need to change the scenario becomes pertinent in science teaching and learning.

Also, to improve academic achievement of students in science and chemistry in particular, this scenario can be replaced by innovation and diversification of strategies in the teaching and learning of science. This idea is in line with the discovery approach of Bruner (1960) as he asserted that learning process should create an environment that will enable learner to find things by himself. Also, the approach coheres with the paradigm shift in the concept of nature of science, which uses the problem solving approach to gain new knowledge. This method is also the focus of modern scientific activity (Wagbara, 2015).

Furthermore, much effort have been made by science educators to diversify teaching and learning strategy from the conventional rote learning method that is teacher centered to activity oriented strategies that focuses more on students creative thinking and interaction with the environment. Oyediji (1997 cited in Ifamuyiwa and Onakoya, 2013) stated that; effective learning of mathematics can be successful when students learn independently and through collaboration. Collaborative learning environment leads to cooperative learning instructional strategy. Cooperative learning strategy is that which enables the learners to work together in small group in such a way that those members can participate clearly as they indulge in discussion among themselves; then actual learning activities relevant to real life that encourages them to teach one another can occur (Adesoji and Ifemuiyiwa, 2007). It is also, Johnson cooperative learning theory which is referred to as think pair-share instructional strategy.

Apparently, several activity oriented learning strategies that has to do with collaboration are inquiry based (Ifamuyiwa and Onakoya, 2013, Wagbara, 2015). It becomes pertinent to choose an effective learning strategy that could involve free inquiry, structured inquiry and guided inquiry that will enable the learner gain appropriate decision and create conclusion of a task, such strategy can enable the learner carry out his own investigation, interact with members of the group to exchange ideas and have interaction with the teacher to gain effective learning (Nbina, 2011).

In this study, it becomes necessary to provide students an environment or situation of participatory learning, that will enable them interact with one another, the teacher and also involve them in creative thinking. Brainstorming is one of the innovative strategies that organize learners into large or small group that indulges in activity that encourages learners to focus on a task and contribute to free flow of ideas (Ajeyalemi and Owoyemi, 2014). Brainstorming is a special way to develop creative thinking as it peculiarly involves working on flow of ideas without criticism as participation of the learners spread thinking and challenges their minds (Hassanin, 2002 cited in Malkawi and Smadi, 2018).

According to Mohamma (2016); Brainstorming is a conglomeration of a relaxed informal approach to problem solving, thinking and lateral performance. For this study, brainstorming is a strategy that organizes learners into participatory small or large groups that indulges in critical thinking that could enhance free flow of ideas among them as 
they interact with the teacher. In a task that involves the teacher in brainstorming, the teacher should emphasize on active listening during the session to provide an opportunity for learners to share ideas and expand their already built knowledge by building on one another contributions. At the end of a brainstorming session, if one goes through the results and evaluate the responses, you will observe attainment of best idea and development of new ideas by the use of the ideas introduced during the session (Abdelkader, 1997, Kittami, 2001, Ajeyalemi and Owoyemi, 2014).

Above all, one of the major tasks of the countries of the world today is development of creative minds in her citizens, which will enable them to be capable of solving existing problems (Malkawi and Smadi 2018). This has warranted the educational system of most countries in the world to shift their goal towards building students' thinking, investment and utilization of their creative potential to solve existing problems (Tabtay, 2001). Brainstorming strategy can build creative thinking, capability of students in solving a task. Hence, it becomes necessary to investigate the effect of brainstorming strategy on senior secondary school students' academic achievement in chemistry.

\section{Purpose of the Study}

The main purpose of this study is to investigate the effect of brainstorming strategy on senior secondary school students' academic achievement in chemistry. Specifically, the study was designed to determine:

1. The effect of brainstorming strategy on academic achievement of students in chemistry.

2. The comparative effect of the use of brainstorming strategy and that of lecture method on mean academic achievement of students in chemistry.

3. Gender effect of the use of brainstorming strategy on academic achievement of students in chemistry.

\section{Research Questions}

1. What is the effect of the use of brainstorming strategy on academic achievement of students in chemistry?

2. What is the mean achievement scores of students taught chemistry by the use of brainstorming strategy and those taught by use of lecture method?

3. What is the mean achievement scores of male and female students taught by use of brainstorming strategy in chemistry?

\section{Hypotheses}

The following null hypotheses which were tested at .05 level of significance further guided the study:

1. There is no significant difference between the mean scores of pretest and post test of the students taught chemistry by the use of brainstorming strategy.

2. There is no significant difference between the academic achievement of students taught chemistry by use of brainstorming strategy and those taught by use of lecture method.

3. Gender does not have any significant effect on mean score of students taught chemistry by use of brainstorming strategy.

\section{Methodology}

The design adopted for this study was quasi experimental research design. The study was carried out in Rivers State Central Educational Zone, Nigeria. A sample size of two hundred (200) SS 2 Chemistry students participated in the study. The purposive sampling technique was used to select Obio/Akpor Local Government Area out of the nine (9) Local Government Areas in Rivers State Central educational zone. A simple random sampling by balloting was carried out to select two (2) public senior secondary schools out of the twenty (20) public senior secondary schools in Obio/Akpor Local Government Area. One of the two selected public senior secondary schools was used for the experimental group (Brainstorming Strategy) while the other was assigned the Control group (Lecture method). Two intact classes of SS2 chemistry students were used for each of the groups (to form a total of 4 intact classes) for the study. The data collected were analyzed by using mean and standard deviation to answer all the research questions while analysis of co-variance (ANCOVA) was used to test the hypotheses at .05 level of significant.

\section{Research Question I}

6. Results

What is the effect of the use of brainstorming strategy on academic achievement of students in chemistry?

Table I: Mean achievement and the standard deviation score of students taught Chemistry by the use of Brainstorming strategy.

\begin{tabular}{llllll}
$\begin{array}{l}\text { Brainstorming } \\
\text { strategy }\end{array}$ & \multicolumn{1}{c}{ Group } & & N & & $\bar{X}$ \\
\hline Pretest & 1 & 50 & & 47.16 & 9.580 \\
& 2 & 50 & & 94.84 & 6.319 \\
& Total & $\mathbf{1 0 0}$ & $\mathbf{7 1 . 0 0}$ & $\mathbf{2 5 . 2 8 4}$ \\
Posttest & 1 & 50 & 50.30 & 8.753
\end{tabular}




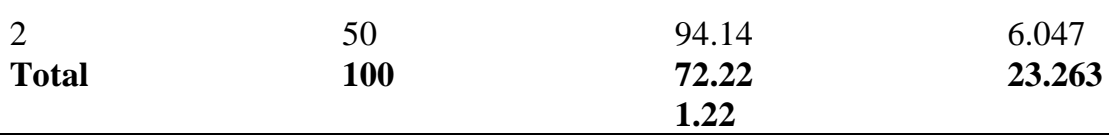

From Table I, it can be observed that the mean score of the pretest group was 71.00 with a standard deviation score of 25.284, whereas the mean score of the students taught chemistry by use of brainstorming in the post test group was 72.22 with a standard deviation of 23.267. The post test group had a higher mean than the pre test group with a mean difference of 1.22. The higher standard deviation (25.284) of the pretest group shows that their mean score deviated more from the mean than that of the post test group. Hence, the higher mean of the posttest group may be real as it appears.

\section{Hypothesis I}

Ho1: There is no significant difference between the mean score of pre test and post test group of students taught chemistry by the use of brainstorming strategy.

Table 2: Analysis of Covariance (ANCOVA) of the effect of Brainstorming strategy on academic achievement of students in Chemistry.

\begin{tabular}{llllll}
\hline Source & $\begin{array}{l}\text { Type III sum of } \\
\text { square }\end{array}$ & df & Mean square & F & Sig. \\
\hline Corrected Model & $48163.438^{\mathrm{a}}$ & 2 & 24081.719 & 430.053 & .000 \\
Intercept & 49771.186 & 1 & 4977.186 & 88.883 & .000 \\
Pretest & 114.788 & 1 & 114.788 & 2.050 & .155 \\
Strategy & 3581.180 & 1 & 3581.180 & 63.953 & .000 \\
Error & 431.722 & 97 & 55.997 & & \\
Total & 575168.000 & 100 & & & \\
Corrected Total & 53595.100 & 99 & & & \\
\hline
\end{tabular}

a. Rsquare (Adjusted Rsquared $=.897$ )

The result of Table 2 was used to determine whether brainstorming has significant effect on mean scores of students of pretest and posttest groups that are taught chemistry. Table 2 shows that an F-ratio of 63.953 with associated probability value 0.00 was obtained. The probability value of 0.00 was compared with 0.05 and it was found to be significant because 0.00 was less than $0.05 \mathrm{P}<.05$. The null hypothesis was therefore rejected and inferences drawn that; brainstorming strategy have significant effect on mean achievement score of students in chemistry.

\section{Research Question 2}

What is the mean achievement scores of students taught chemistry by the use of brainstorming strategy and those taught by the use of lecture method?

Table 3: Mean achievement and standard deviation scores of the students taught Chemistry by the use lecture method.

\begin{tabular}{|c|c|c|c|c|c|c|c|}
\hline $\begin{array}{l}\text { Two strategies exposed } \\
\text { to students in Chemistry }\end{array}$ & $\mathbf{N}$ & & Pretest & $\mathbf{N}$ & & ttest & Mean \\
\hline & & $\bar{X}$ & SD & & $\bar{X}$ & SD & Gain \\
\hline Lecture (control) & 100 & 47.69 & 9.457 & 100 & 63.71 & 15.146 & 16.02 \\
\hline $\begin{array}{l}\text { Brainstorming } \\
\text { (Experimental) }\end{array}$ & 100 & 48.56 & 9.151 & 100 & 94.77 & 5.784 & 46.21 \\
\hline Mean Diff. & & & & & 31.06 & & \\
\hline
\end{tabular}

Table 3 shows the mean achievement scores of students exposed to two instructional strategies (lecture and brainstorming). From Table 3 mean achievement scores of 47.69 and 48.56 with standard deviation of 9.457 and 9.151 were obtained for lecture and brainstorming strategies respectively in the pre test group. Furthermore, in the post test group mean achievement scores of 63.71 and 94.77 with associated standard deviation of 15.146 and 5.784 were obtained respectively for both lecture and brainstorming strategies. Mean gain of 16.02 and 46.21 were recorded for the two strategies (Lecture and Brainstorming). Also, in the post test, the mean difference for lecture method and brainstorming strategy had a higher mean of 94.77 with associated standard deviation of 5.781 while lecture strategy had a mean of 6.71 with standard deviation of 15.146. The higher standard deviation of the lecture strategies means that their scores deviated from the mean more than that of brainstorming strategy. Hence, the higher mean of brainstorming strategy may be real as it appears.

Hypothesis 2

$\mathrm{Ho}_{2}$ : There is no significant difference between the academic achievement of students taught chemistry by use of brainstorming strategy and those taught by use of lecture method.

Table 4: Analysis of Covariance of students' achievement scores on two instructional strategies, lecture and Brainstorming strategies

\begin{tabular}{|c|c|c|c|c|}
\hline Source & $\begin{array}{l}\text { Type III sum of df } \\
\text { squares }\end{array}$ & Mean square & $\mathbf{F}$ & Sig. \\
\hline
\end{tabular}




\begin{tabular}{llllll} 
Corrected Model & $49254.570^{\mathrm{a}}$ & 3 & 6418.190 & 127.278 & .000 \\
Intercept & 25973.941 & 1 & 25973.941 & 201.357 & .000 \\
Pretest & 509.265 & 1 & 509.265 & 3.948 & .048 \\
Method & 49144.061 & 2 & 24572.030 & 190.289 & .000 \\
Error & 25282.950 & 196 & 128.995 & & \\
Total & 1328432.000 & 200 & & & \\
Corrected Table & 74537.520 & 199 & & & \\
\hline
\end{tabular}

a. $\mathrm{R}$ squared $=661$ (Adjusted $\mathrm{R}$ squared $=.656$ )

The result in Table 4 was used to determine whether there was significant difference between the academic achievement of students taught chemistry by the use of brainstorming strategy and those of lecture method. Table 4 shows that an F-ratio of 190.289 with associated probability value of 0.00 was obtained. The probability value of 0.00 was compared with .05 level of significance and it was found to be significant because 0.00 was less than .05 . The null hypothesis two $\left(\mathrm{Ho}_{2}\right)$ was therefore rejected and inference drawn that; there is significant difference between the academic achievement of students taught chemistry by the use of brainstorming strategy and those taught by use of lecture method. Research Question 3

What are the mean achievement scores of male and female students taught by the use of brainstorming strategy in chemistry?

Table 5: Mean achievement and standard deviation scores of male and female students taught Chemistry by the use of Brainstorming strategy.

\begin{tabular}{lllll}
\hline $\begin{array}{l}\text { Brainstorming } \\
\text { strategy }\end{array}$ & Gender & $\mathbf{N}$ & $\bar{X}$ & SD \\
\hline Pretest & Male & 50 & 47.96 & 9.837 \\
& Female & 50 & 50.10 & 8.758 \\
Posttest & Mean Dif. & 50 & 2.14 & 5.632 \\
& Male & 50 & 95.56 & 6.269 \\
\hline
\end{tabular}

Table 5 shows that the mean achievement score of the male students taught chemistry by use of brainstorming strategy was 47.96 with associated standard deviation of 9.837 while the mean achievement score of the female students was 50.10 with standard deviation 8.578 in the pretest group. Their mean achievement score difference was 2.14 . In the post test group Table 5 shows that, mean achievement score of the male students was 95.56 with standard deviation score of 5.632 while the female students had a mean achievement score of 93.96 with associated standard deviation score of 6.269 in chemistry. The gender mean achievement score difference in chemistry was 1.6. The higher standard deviation (6.269) of the female students indicates that their scores deviated more from the mean than that of the male students. Hence, the higher mean of the male students may be real as it appears.

Hypothesis 3

$\mathrm{Ho}_{3}$ : Gender does not have any significant effect on mean score of students taught Chemistry by the use of Brainstorming strategy.

Table 6: Analysis of Covariance of gender effect on mean achievement score of students taught chemistry by the use of brainstorming strategy.

\begin{tabular}{llllll}
\hline Source & $\begin{array}{l}\text { Type III sum of } \\
\text { squares }\end{array}$ & df & Mean square & F & Sig. \\
\hline $\begin{array}{l}\text { Corrected } \\
\text { Model }\end{array}$ & $73.940^{\mathrm{a}}$ & 2 & 36.970 & 1.032 & .360 \\
Intercept & 31762.092 & 1 & 31762.092 & 887.797 & .000 \\
Pretest & 9.940 & 1 & 9.940 & .278 & .599 \\
Gender & 57.505 & 1 & 57.505 & 1.607 & .208 \\
Error & 3470.300 & 97 & 35.776 & & \\
Total & 901490.000 & 100 & & & \\
Corrected Total & 3544.240 & .240 & 99 & & \\
\hline
\end{tabular}

a. $\mathrm{R}$ squared $=.021$ (Adjusted $\mathrm{R}$ Squared $=001$ )

The result in Table 6 was used to determine whether gender have significant effect on mean achievement score of students taught chemistry by the use of brainstorming strategy. Table 6 shows that, an F-ratio of 1.607 with associated 
probability value of .208 was obtained. The probability value of .208 was compared with .05 and it was found not to be significant because .208 was greater than .05 . The null hypothesis was therefore accepted and inference drawn that, gender does not have significant effect on mean achievement score of students taught chemistry by the use of brainstorming strategy.

\section{Discussion}

The result of Analysis of Co-variance (ANCOVA) used in testing hypothesis one as shown in Table 2 yielded an F-ratio of 63.953 and associated probability value of .00 . The result of the study shows that $\mathrm{P}<.05$ and brainstorming strategy have significant effect on students' academic achievement in chemistry. Hence, null hypothesis one (Ho $\left.{ }_{1}\right)$ of this study which states that, there is no significant difference between the mean score of pre test and post test group of students taught chemistry by use of brainstorming strategy was rejected. The finding of this study is in line with the findings of Mohammed (2016), Malkawi and Al Balqa (2018) which states that there is significant difference between the experimental group and the control group in favor of the brainstorming strategy. This study has confirmed that there is significant difference between the mean scores of pre test and post test of the students taught chemistry by the use of brainstorming strategy.

Table 4 shows that, an F-ratio of 190.289 was obtained with associated $\mathrm{P}<.05$. The result of the study showed that there is significant difference between the academic achievements of students taught Chemistry by the use of brainstorming strategy and those taught by the use of lecture method. Hence, the null hypothesis two $\left(\mathrm{Ho}_{2}\right)$ of the study which states that there is no significant difference between the academic achievement of students taught chemistry by the use of brainstorming strategy and those taught by use of lecture method was rejected. The finding of (Mohammed, 2016, Malkawi and Al Balqua, 2018) were in support of this study as they state that the modern method of teaching including brainstorming is more effective than traditional like lecture method. This study confirmed that, brainstorming was significant on student's achievement in chemistry.

The result in Table 6 shows that, an F-ratio of 57.505 was obtained with associated P > .05. Table 6 shows that there is no significant difference between the mean achievement of the male and female students taught chemistry by use of brainstorming strategy. The findings of this study was not supported by (Mohammed, 2016, Malkawi and Al Balqua, 2018) as they stated that there is significant difference between the male and female students taught English by use of brainstorming strategy in favor of the females. However, this study has confirmed that there is no significant difference between the academic achievement of the male and female students who are taught chemistry by use of brainstorming strategy.

\section{Conclusion and Recommendations}

Firstly, this study has shown that brainstorming strategy have significant effect on academic achievement of students in chemistry. Hence, it becomes necessary that chemistry teachers should use brainstorming strategy which is more of discovery approach to improve achievement of students in chemistry. It also, pertinent to use brainstorming strategy for students in the learning of chemistry as it encourages the use of the problem solving approach to gain new knowledge which coheres with the concept of the nature of science.

Secondly, the result of this study has also shown that, there was significant difference between the academic achievement of students taught chemistry by the use of brainstorming strategy and that of lecture method in favor of brainstorming strategy. Hence, it becomes pertinent to diversify the method of teaching chemistry from lecture method to a modern activity oriented method of brainstorming strategy that focus on student's creative thinking and collaboration among the students.

Thirdly, it was found that, the result of this study showed that, gender does not have any significant effect on mean score of students taught chemistry by the use of brainstorming strategy. Hence, equal learning opportunities should be given to both male and female students that are taught chemistry by the use of brainstorming strategy. The chemistry teacher should also guide the students and ensure good collaboration exist among the students for good relationship and share of ideas among them for higher achievement of the students in chemistry.

\section{References}

1. Adesoji, F.A. and Ifanmuyiwa, S.A. (2007). Enhancing Senior Secondary School Students' Cognitive Achievement in Mathematics through self and Cooperative instructional strategies. European Journal of Scientific Research 18(3), 402 - 416.

2. Abdelkader, M. (1997). The effect of using brainstorming in teaching Biology on the development of some biological concepts and scientific thinking among pupils in first secondary grade. Educational Journal 12(1), 1 -31 .

3. Adeyalemi, D. and Owoyemi, T.E. (2014). A handbook for chemistry strategies for Teaching carbon and its compound, Hydrocarbon and crude oil of senior secondary school. Science Teachers Association of Nigeria, Zaria, Nigeria Machim Multimedia Designers Publishers.

4. Bruner, J. (1960). The process of Education Cambridge, M.A. Harvad University Press. 
5. Ifemuyiwa, S.A. and Omakaya, S.K. (2013). Impact of Think-pair-share Instructional strategy on students' Achievement in secondary school mathematics. Journal of the Science Teachers Association of Nigeria 48(1), 27 -35 .

6. John, M.D. and Johnson, F. (1999). Working together; Group theory and group skills, $5^{\text {th }}$ Edition Boston: Allyum and Bacon.

7. Kittami, N. (2001). Teaching Thinking in the Basic Stage. Amman, Dar-el-Fikr.

8. Mohammad, K.H. (2016). Effect of Brainstorming Strategy Students Achievement in the course of EIOI and its relation to some variables. Journal of Literature Language and Linguistics. 20, 81 - 86

9. Malkanai, N.A.M. and Smadi, M. (2018). The Effectiveness of using Brainstorming strategy in the Development of Academic Achievement of Sixth Grade Students in English Grammar at Public Schools in Jordan International Education Studies 11(3), 92 - 100.

10. Nbina, J.B. (2011). A handbook of laboratory organization and management. Port Harcourt Nigeria, Paragraphic Publishers Services.

11. Tabtay, M. (2001). Developing creative thinking capability. Dar. Al Masriah Publishing and Printing ( $1^{\text {st }}$ ed.) Amma Jordan.

12. Wagbara, O.S. (2015). Influence of Cognitive Style on Secondary School Students Interest and acquisition of practical skills in Chemistry Unpublished student Ph.D Thesis, University of Nigeria. 